\section{World Eco-Crisis}

\section{International Organizations} in Response

Edited by David A. Kay and

Eugene B. Skolnikoff

Introduction by Maurice Strong

This is the first book to analyze the impact and implications of the environmental crisis for international organizations World Eco-Crisis takes up the issues faced at the UN Conference on the Human Environment, often by

Conference participants. (Reproduces the

Spring 1972 issue of International Organization.) 300 pages

cloth \$12.50; paper $\$ 2.50$

\section{Inlernalional Organizalion}

A quarterly journal sponsored by the World Peace Foundation and the University of Wisconsin

David A. Kay, Editor

Regular issues of International Organization contain critical articles, and extensively annotated and factual summaries of recent United Nations activities, UN specialized agencies, and the principal political, regional and functional international organizations. A special issue is published each year. Individuals $\$ 10,00 / \mathrm{yr}_{\text {; }}$ Institutions $\$ 20.00 / \mathrm{yr}$.

\section{Man in the Living Environment}

\section{A Report on Global Ecological Problems}

Sponsored by the Institute of Ecology

This report, the work of a group of fifty topranking scientists, was prepared to transmit the ecologist's view of global ecological problems to the Stockholm Conference. Discussed are issues concerning population and resources management. pollution, chemical and biological pest control, crop and habitat management. land and aquatic food sources, eutrophication of land and water, and the effects of human activity upon element cycles

300 pages

cloth \$12.50; paper $\$ 2.50$

Wisconsin residents add $4 \%$ sales tax

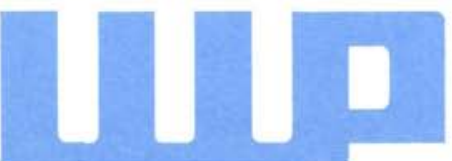

\section{Water Resources Law an Policy in the Soviet Unior}

Edited by Irving K. Fox

The management of water resources has just! become a subject of international concern. Until now, a text-in English-delineating Soviet water law and policy has not been available. This volume fills that gap in the literature, and sheds new light on problems relating to US. water assets. (University of Wisconsin Water Resources Studies, V. 1)

264 pages

cloth $\$ 8$

\section{Soviet Prison Camp Speech}

\section{A Survivor's Glossary}

Supplemented by terms from the works of A. I. Solženicyn

Compiled by Meyer Galler and Harlan E. Marquess

This glossary, the only one of its kind, will be of significant interest and value to Russiar reading historians and political scientists, and to all who read recent Russian literature especially the underground genre. The more than one thousand words and expressions in the glossary, listed alphabetically in Russian Cyrillic, are defined in both Cyrillic and in English. Also included is an explanation of th glossary's origin and an introduction which places Soviet prison camp speech in historici and linguistic perspective.

152 pages

cloth $\$ 10$

\section{Africa and the West \\ Intellectual Responses to European Culture}

Edited by Philip D. Curtin

In this new volume. Curtin's latest effort, he presents seven essays which together help to reconstruct Africans views of the West over the past hundred years. The work is one of intellectual history, approached not only by historians but by anthropologists and literary critics as well. Contributors include James W. Fernandez, Wyatt MacGaffey, Jean Herskovit G. Wesley Johnson, Jr., Leo Spitzer, Harold Scheub, and Curtin.

280 pages

cloth $\$ 12$ 


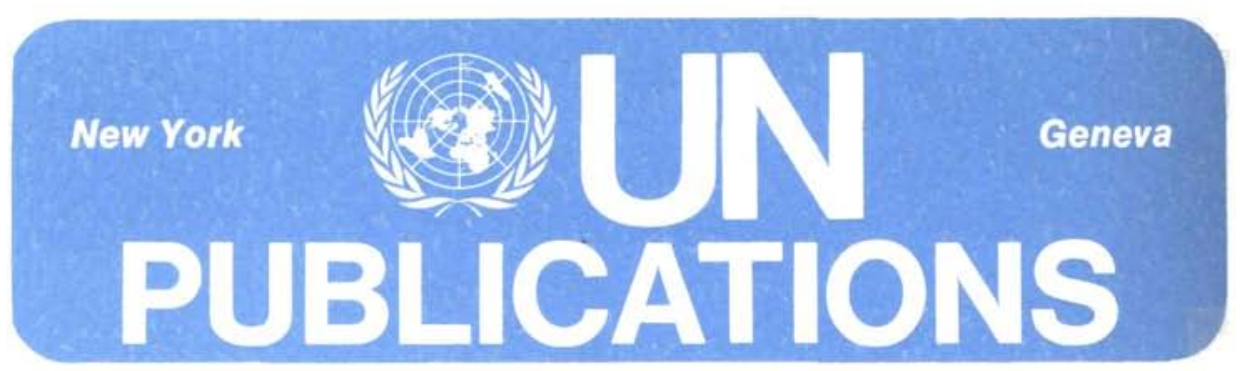

\section{ESSENTIAL FOR THE UNITED NATIONS SHELF}

\section{YEARBOOK OF THE}

\section{UNITED NATIONS, 1969}

The principal reference work of the Organization, the YEARBOOK is intended to present factually, conveniently and concisely, within a single, fully indexed volume, the basic information needed to help towards understanding, and following, the workings of the United Nations system.

Clothbound $\$ 27.00$

\section{Statistical Yearbook.1970}

Comprehensive collection of international statistics relating to such items as population, energy, health, housing and many more.

Clothbound $\$ 22.00$
Paperbound $\$ 15.00$

Demographic Yearbook,1970

International demographic survey of statistics for over 250 countries and territories on population trends, marriages, divorces, births, deaths and expectation of life.

Clothbound $\$ 22.00$
Paperbound $\$ 15.00$

Yearbook of International Trade Statistics.1968

A compilation of national tables showing annual figures for several years for over 138 countries and territories, and summaries of trade by large commodity classes and by principal regions and countries.

Paperbound $\$ 12.50$

\section{EVERYMAN'S UNITED NATIONS}

The Eighth Edition contains the basic history of the Organization from 1945 to 1965 and is a complete handbook of the functions and activities of the United Nations and its related agencies during those 20 years.

The Supplement covers the years 1966 to 1970.

Together they constitute a complete history for the past 25 years.

Eighth Edition Clothbound $\$ 6.00$ Paperbound $\$ 2.50$

Supplement Clothbound $\$ 4.00$ Paperbound $\$ 1.95$

Special price for both volumes:

Clothbound $\$ 7.50$

Paperbound $\$ 3.95$

\section{UN Monthly Chronicle}

Designed for everyone learning or teaching about the United Nations. Its follow-up on world events and quotations from important speeches and documents provides the best explanation of what the United Nations is, its aims and achievements.

Annual subscription U.S. and Canada $\$ 9.50$ Other parts of the world $\$ 4.75$

Yearbook of National Accounts Statistics.1969

Vol.I Country Data 864 p. $\$ 12.50$

Vol. II International Tables

226 p. $\$ 3.50$

\section{UNITED NATIONS PUBLICATIONS}

